\title{
Den impotente vampyren? Vampyrer och sexualitet i den samtida vampyrromanen
}

\section{Av Anna Höglund}

\section{Länk till presentation av Anna Höglund}

- Inledning

- Vampyren och sexualiteten

- Själens bikt och bekännelse

- Den impotente vampyren

- Människans sexualitet sedd med vampyrens ögon

- Vampyrens hunger

- Kan en studie av vampyrens matvanor öppna för nya perspektiv på vampyrmotivet?

- Sammanfattning och konklusion

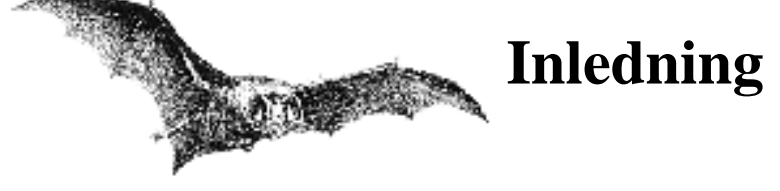

Vampyren hemsöker vår kultur. Stripteasevampyrer, homosexuella vampyrer, fettsugande vampyrer, "splatterpunk"-vampyrer, guldlockiga barnvampyrer, militanta veganvampyrer och sist men inte minst blåblodiga vampyrer.

Nedan skall jag presentera några av de iakttagelser som jag gjort inom mina studier av det litterära vampyrmotivet.

I min forskning har jag ställt vår tids vampyrroman i fokus. Inom den akademiska forskningen har den nutida vampyrromanen inte undersökts särdeles utförligt. Äldre tiders litterära vampyrmotiv har däremot inte gått obemärkt förbi den akademiska luppen, och i centrum för forskningen står klassikern Bram Stokers Dracula.

\author{
Varney The \\ Vampire or The \\ Feast of Blood \\ (1840-1847) är \\ genrens mest \\ omfattande verk. \\ Boken skrevs \\ som följetong av \\ ett författarteam \\ för den tidiga \\ massmarknadens \\ publik. Sett i \\ historiens ljus \\ kom Varney The \\ Vampire att bilda \\ länken mellan \\ romantikens
}




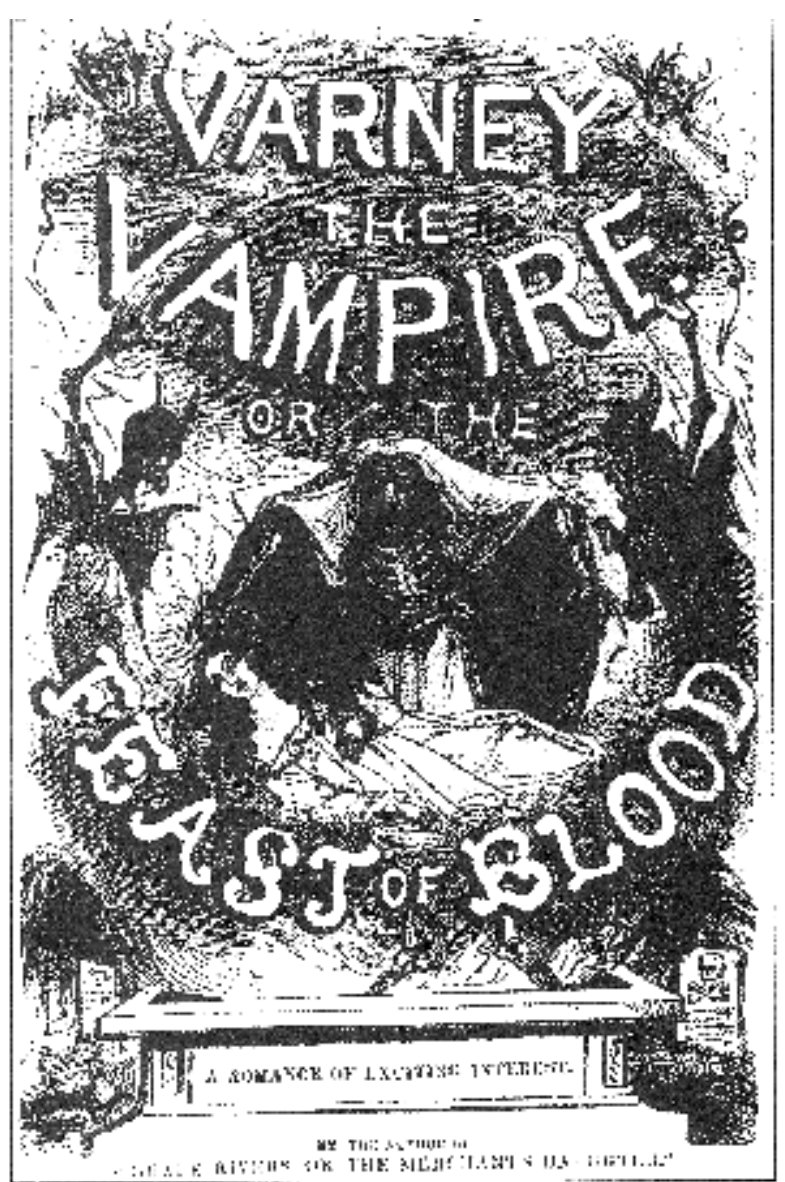

vampyrberättelser och Bram Stokers Dracula och i verket sammanfördes de flesta av de ingredienser som efter Dracula kom att bilda ett fast fundament för vampyrromanens vidare utveckling.

Den australiensiske cultural studiesforskaren Ken Gelder påstår i Reading the Vampire med rätta, att det har vuxit fram en akademisk industri kring Dracula.[1] Det är inte underligt eftersom romanen rymmer en mängd infallsvinklar som befunnits användbara av forskare från skilda discipliner och forskningsfält. Civilisationsteorin, rättspsykiatrin, antisemitismen, orientalismen, kolonialismen, kapitalismen, liberalismen, marxismen, positivismen och feminismen är bara några av de teorier och ismer som presenterats och analyserats utifrån exemplet Dracula. Men det ämne som toppat den akademiska diskussionen kring vampyrmotivet är sexualiteten.



I tolkningar av sexualiteten i vampyrlitteraturen, däribland Dracula, har psykoanalysen spelat en central roll. Dracula publicerades år 1897. Det är ett år efter det att termen psykoanalys introducerades. I Dracula spelar studiet av människans hjärna och det omedvetna en central roll. Det figurerar två doktorer i romanen, Dr Van Helsing och Dr Seward. De är båda intresserade av att utforska människans inre universum. Dr Van Helsing är en beundrare av den store Charcot och han praktiserar hypnos.[2] Dr Seward är föreståndare för ett mentalsjukhus och han arbetar med att försöka förstå och förklara galenskapen hos patienten Renfield.

En tidig psykoanalytiskt influerad tolkning av Dracula finner man i Ernest Jones On The Nightmare från 1929. Jones menar att monstret Dracula är en indikator på skiftande former av sexuella perversioner. Vampyrtron är en fantasi som härrör från en infantil sexuell 
ångest, där de mer perversa formerna av sexualitet manifesterar sig. Jones härleder vampyrens blodsugande till en slags oral sadism där sugandet (love) övergår i bitande (hate).[3]

Flera kritiker har påvisat incesttabut i Dracula och i James Twitchells "The Vampire Myth" (1980) för han fram teorin att vampyren är den onde fadern som kämpar med sina söner om kärleken till modern. Han berör även vampyrmotivet inom dagens populärkultur, då främst inom film, och påstår att konsumenten, i detta fall främst unga pojkar, upplever en "masturbatory delight" när de ser den potente vampyren förgripa sig på det kvinnliga offret.[4]

Phyllis A Roths tar i sin feministiska läsning "Suddenly Sexual Woman in Bram Stokers Dracula" (1977) fasta på moderns roll istället för faderns och påstår att romanen huvudsakligen uttrycker ett patriarkalt hat riktat mot modern.[5]

Inom queer studier och inom forskningen kring homosexualitet har vampyren kommit att bli föremål för en mängd tolkningar som syftat till att förklara hur de som avvikit ifrån den accepterade heterosexuella normen uppfattats av samhället. Eve Kosofsky Sedgwick lyfter i boken Between Men (1985) fram det homosociala spelet mellan männen i Dracula och hon diskuterar därutöver den skräckromantiska vampyrfiktionens gestaltande av den aristokratiska mannen som queer.[6] Även Trevor Holmes ser närmare på gestaltandet av den homosexuelle mannen i "Coming out of the Coffin: Gay Males and Queer Goths in Contemporary Vampire Fiction ".[7] Miriam Jones "The Gilda Stories: Revealing the Monsters at the Margins" och Sue Ellen Cases "Tracking the Vampire" riktar sitt fokus på framställningen av den lesbiska kvinnan.[8] Skräckromantikens populärfiktion har även analyserats av Maurice Richardsson i essän "The Psychoanalysis of Ghost Stories' (1959). Maurice Richardsson som ser genren som sensationshungrande menar att det som lockar är vampyrens polymorfa sexualitet. Här finner man det verkligt tabubrytande. Vampyren bryter inte bara ett specifikt sexuellt tabu utan han bryter alla.[9]

Richardssons tes får avsluta min korta genomgång av forskningen kring vampyrens sexualitet eftersom den kan sägas sammanfatta dess resultat. Forskningen kring vampyrmotivet för fram bilden av vampyren som en potent erövrare som inte hyser några samvetsbetänkligheter då han styrd av sina okontrollerbara lustar och begär bryter alla de sexuella tabun som den västerländska kulturen ställt upp.

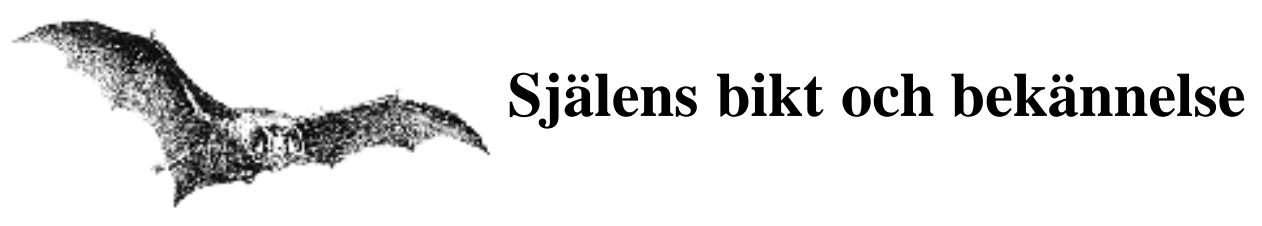

Psykoanalysen har visat sig användbar då man tolkat vampyrmotivet i litteraturen och kulturen. Men psykoanalysen eller snarare gestaltningen av det undermedvetna har även haft en särställning inom vampyrlitteraturgenren som sådan. I stort sett i all litteratur där motivet spelar en central roll återfinns psykoanalysen i en eller annan form. Redan innan termen psykoanalys introducerades är individens strävan efter att förklara dolda begär och trauman ett centralt inslag i vampyrlitteraturen. Under 1700- och 1800-talen sker detta ofta i form av en själens bikt eller bekännelse given av vampyrens offer eller andra människor i dess omgivning.

I den nutida vampyrromanen är bekännelseförfarandet minst lika närvarande, men det har numera skett en perspektivförändring. Offret eller människan står inte ensam för själens bikt utan nu är det vampyren som lättar sitt hjärta. Idag blottar vampyren sitt innersta rum, det som under 1800-talet förblev dolt.

Det litterära greppet att införa en annorlunda berättarposition har medfört drastiska 
förändringar av genrens karaktär samtidigt som den bibehållit mycket av de traditionella bärande elementen. En klar likhet mellan den äldre litteraturen och vår samtida är den att trots att vampyren ofta är romanens huvudperson eller nyckelfigur, tycks hans huvudsakliga syfte vara att bilda en passande fond för människans värld. Man kan möjligen jämföra förfarandet med orientalistens ansats, enligt Saids mening. Orientalisten beskriver det andra landet och den andra kulturen för att på så sätt framhäva eller beskriva den egna.[10]

Det finns dock en radikal skillnad mellan den äldre vampyrromanen och den nutida. I 1700-talets och 1800-talets litteratur är det människan som för talan för både den andre, det vill säga vampyren, och sig själv.[11] I den nutida romanen är förhållandet dock det motsatta. Nu är det vampyren som exotiserar, det är han som har tagit på sig orientalistens, antropologens eller kultursociologens roll, och det är han som innehar förmågan att iaktta och beskriva den andra kulturen och den egna. Eftersom vampyren en gång varit människa har han det dubbla seende som tillskrivits vad Stonequist kallat för the marginal man och vars position han och Bhabha benämnt som "in between".[12] Han kan inte gå tillbaka till att bara vara människa, och han kan inte, åtminstone inte alltid, förneka sitt sociala arv. Han tvingas därmed hantera och bearbeta den marginella position som han placerats i.

När det gäller förmågan att förneka sitt sociala arv och ställa sig helt utanför eller i de flesta fall ovanför den mänskliga världen så föreligger det en viss individuell skillnad mellan olika sorters vampyrer, eller kanske snarare stadier av vampyrism. I den nutida vampyrromanen kan man grovt indela vampyrerna i två typkategorier. Den första typen är vad man i brist på bättre beteckning kan kalla monstervampyren. Det är den vampyr som förlorat i stort sett alla mänskliga egenskaper. Monstervampyrerna beskrivs som samvetslösa mördare som överhuvudtaget inte reflekterar över människornas värld annat än som föda. De ser sig själva som övermänniskor som likt Machiavellis furste med rätt gör vad de behagar.

Monstervampyren är anonym, han delar sällan med sig av sitt inre känsloliv. Det gör däremot den andra kategorin som jag tillfälligt kallar för humanvampyren.

Humanvampyren har inte fullt lämnat sitt mänskliga vara. Han står med det ena benet i människornas värld och det andra i vampyrens eller monstrets. Humanvampyren är i stort sett alltid huvudperson i den nutida vampyrromanen.

Humanvampyren vill förstå sin existens och han vill lära känna sitt inre. För det behöver han verktyg, verktyget han finner är analysen. Den moderna vampyren är inte sen att utnyttja de möjligheter som den mänskliga världen erbjuder honom för att få insikt i sitt undermedvetna. I mer abstrakt mening är det den mänskliga världen som utgör den spegel som tillåter honom att förstå sig själv, i en mer konkret praktik är det även där som han kan utföra sin analys. Han skaffar sig resolut sin egen välutbildade analytiker. Med hjälp av Freud eller Jung börjar han sin långa resa mot självinsikt.

Vad innebär då de förändringar av berättarperspektivet som jag beskrivit för gestaltandet av sexualiteten i den nutida vampyrromanen? Idag är sexualiteten fortfarande ett centralt tema. Liksom tidigare behandlas främst de mörka sidorna, våldet, perversiteterna och övergreppen. Men sexualiteten är inte dold som i 1800-talslitteraturen. Den är exponerad och man har lyft fram den i ljuset och nu är det inte endast vampyrens offer eller de mänskliga agenterna som rör sig kring vampyren som biktar och analyserar sina sexuella trauman, utan även vampyren.

Skall då vampyren en gång för alla krypa till korset och likt Don Juan och Casanova avslöja allt om sina sexuella utsvävningar? Nej då, jag vill påstå att vampyrens sexuella trauman inte främst handlar om hans utövande av de mörka sidorna av sexualiteten, om hans oförmåga att kontrollera sina sexuella lustar, utan att den snarare berör en motsatt problematik. Forskningen kring vampyrens roll i text och kontext för fram bilden av vampyren som en hänsynslös erövrare som inte hyser några skrupler då han praktiserar totalt kravlöst sex. Vampyren har brutit sig loss från de sexualitetens bojor som fängslar människan. Han tar vad han vill ha och flyger därefter ogenerat och oreflekterat vidare till 
nästa offer. Detta är en uppfattning som jag antar överenstämmer med gemene mans. Urvampyren Draculas efterföljare har, inte minst på film, antagit gestalten av den mörke älskaren. Se bara på Hammer Film Companys vampyrer i Bela Lugosis och Christopher Lees gestalt eller Universal Films kvinnotjusare Frank Langella. Under min läsning av vampyrromanen har dock en mer nyanserad bild av vampyren växt fram och med avstamp i den vill jag hävda att den nutide vampyren bearbetar en impotens- snarare än en potensproblematik. Därutöver har vampyren blivit monogam. När han älskar, älskar han endast en utvald partner som han vill leva med i evighet.

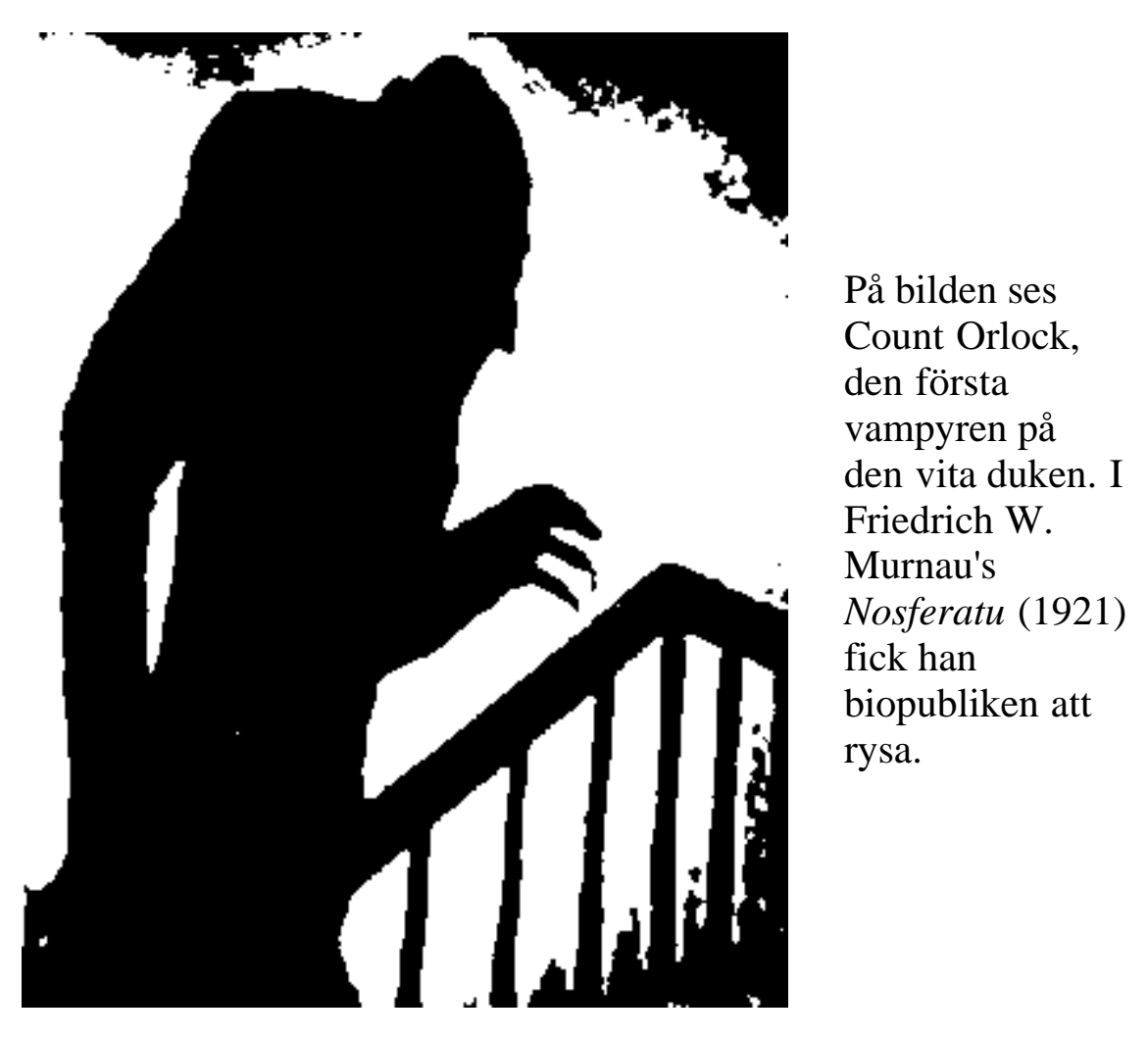

\section{Den impotente vampyren}

I S.P Somtows Vampire Junction (1984) möter vi den undersköne popidolen och vampyren Timothy Valentine. Timmy ser ut som om han nyss fyllt tolv år men egentligen är han över tvåtusen år gammal. Trots sin avsevärda ålder befinner han sig i en slags pubertal identitetskris och han börjar gå i terapi. Denna är framgångsrik. Genom att låta Timmy återuppleva traumatiska sekvenser under sitt livs historia når hans terapeut fram till ångestens primala kärna. Innan Timmy förvandlades till vampyr blev han kastrerad. Vampyrens frustration och ångest bottnar i att han förlorat sin potens och i att han under hela sitt tvåtusenåriga liv aldrig fått uppleva hur det är att älska på det sätt som människorna gör.

Liknande frustration som hos Timmy finner vi hos Claudia, den lilla vampyrflickan i Anne Rices Interview with the Vampire (1976). Claudia blir vampyr redan som litet barn och eftersom en vampyr sällan åldras så fängslas hon likt Timmy i ett barns kropp. Hon blir bestulen på upplevelsen av att mogna till kvinna.

För den vuxne vampyren tycks förlusten av den mänskliga potensen inte vara lika 
traumatisk. Vampyren greve de Saint-Germains, huvudpersonen i Chelsea Quinn Yarbros roman Hotel Transylvania (1978), har accepterat sitt öde utan den minsta bitterhet. Om någon av hans beundrarinnor misstolkar hans höviska uppvaktning ler han bara roat och påpekar att det var mycket, mycket länge sedan han slutade med sådana saker.

Beundrarinnorna nöjer sig allt som oftast med svaret eftersom de konstaterar att det inte existerar några skamliga rykten om greven och att det skvallras om att han troligen lever i celibat, eftersom han trots envis uppvaktning av både män och kvinnor inte lockats till älskog.

Under min läsning av vampyrromaner har jag bara funnit ett fåtal vampyrer som inte förlorat sin mänskliga sexuella potens.[13] Ett av de få undantagen som bekräftar regeln heter Dr Weyland och han figurerar i Suzy McKee Charnas The Vampire Tapestry (1980). Weyland är ett unikum inom den nutida vampyrromanen. Men trots att han inte är impotent har han tagit avstånd från det mänskliga samlaget. Han konstaterar skarpt att man inte kopulerar med sin mat, med boskapen. Sexualiteten har ingen makt över honom utan han har valt bort den.

Gestaltningen av den nutida vampyrens sexualliv är komplex, och den rymmer därmed även vampyrer som till skillnad från Saint-Germain och Dr Weyland näppeligen kräver någon större bearbetning för att lockas till sänghalmen. I Michael Romkeys I, Vampire säger romanens huvudperson:

Women are my weakness. Or to be more accurate. I should say they are my greatest weakness, for I have many. Travel. Books. Classical music. Art. Excellent wine. And, formerly cocaine. I admit these things without a sense of guilt. I am, as my friend from Vienna says, a man with a mans contradictions (...) I am neither good nor bad, neither angel nor devil. I am a man. I am a vampire.[14]

Till Romkeys vampyrs utmärkande karaktärsdrag hör inte ödmjukhet. Det gör däremot, enligt min mening, bristen på självinsikt. Det råder ingen tvekan om att vampyren är svag för kvinnor. Han konsumerar dem flitigt och ställd under dagens läkarvetenskapliga lupp hade hans beteende troligen diagnostiserats som uttryck för en sexuell beroendeproblematik. Kvinnor konsumeras av vampyren i samma syfte som kokain, alkohol och resor; de ger glömska och tröst för stunden och hjälper honom att dämpa sin rädsla för världen utanför drogruset och de skuldkänslor han hyser för sin oförmåga att hantera den. Likt övriga vampyrer jag beskrivit står hans kärlek endast till en kvinna, prinsessan Tatiana Nicolaievna Romanov.

Det är utmärkande för den nutida vampyren att den som har älskat både som människa och vampyr finner att praktiken att älska i människornas värld är ytlig och på alla sätt ofulländad. Vampyren Louis som likt Claudia figurerar i Interview with the Vampire säger att upplevelsen att älska som människa var något som gick snabbt och någonting han sällan njöt av. Louis är en vampyr som inte förlorat sin förmåga att älska och känna empati. Först riktas hans kärlek till vampyrflickan Claudia, men när hon mördas finner Louis så småningom en ny vampyr att dela sitt utanförskap med, Armand. Armand är vampyrernas urfader, dess okrönte konung, och han besitter en kunskap och visdom som Louis åtrår. Armand å sin sida drabbas av stark passion till Louis. Louis representerar för Armand en ny typ av vampyr som till skillnad från alla andra lyckats bibehålla något av sin mänsklighet. Louis utgör en länk mellan den äldre tiden, det förflutna, och den nya tiden, framtiden. När jag läste Interview with the Vampire tänkte jag osökt på myten om fiskarkungen. Armand befinner sig likt Amfortas, fiskarkungen, i ett stadium mellan liv och död. Han är inte endast impotent utan till hela sin uppenbarelse steril. Louis är en vampyrernas Parcifal som kan vitalisera inte endast den sjuke Armand utan hela den ofruktbara urholkade öde värld över vilken han regerar. Som i sagan om Parcifal och fiskarkungen kan läkningsprocessen endast påbörjas genom de av kärlek uttalade orden. Louis och Armands åtrå kanaliseras i nära känsloladdade samtal om livet och icke livet, och den är på alla plan befriad från människornas könsfixerade sexuella praktik.[15] 


\section{Människans sexualitet sedd med}

\section{vampyrens ögon}

Offrets upplevelse av vampyrens närmande har inte genomgått någon radikal förändring under historiens gång. Det upplever liksom på 1800-talet en stark erotisk laddning när vampyren suger dess blod. Vampyren hyser dock förakt för den mänskliga sexualiteten. Offret betraktas som styrt av en instinkt som är lätt att manipulera, en svaghet som vampyren inte är sen att utnyttja.

Vampyren är, för att använda sig av Stephen Greenblatts terminologi, en maktimprovisatör. Han känner sitt offer och han får henne att ge sig till honom av egen fri vilja. Strategin kan sägas vara typisk för vampyren både i 1800- och 1900-talens litteratur. Men samma utveckling som Foucault påvisar i människans värld sker i vampyrernas. Den diciplinära makten tar sig allt subtilare uttryck och betoningen på offrets egna vilja att bli offer är än mer framträdande i 1900-talsromanen än i 1800-talets litteratur.

När vampyren manipulerar sina offer framgår det tydligt att han ser människan som stående på ett lägre utvecklingsstadium. Det är intressant att notera eftersom det i 1800-talets litteratur med få undantag är vampyren som beskrivs som en primitiv art. I Dracula är vampyren en atavism, en förbrytargestalt med outvecklad hjärna. Han är närmare djuren, något som understryks av att han kan växla mellan djurgestalt och människogestalt. Därmed är även Draculas och de övriga vampyrernas sexuella uttryck primitiva. Den okontrollerade, ohämmade sexualiteten tillhör en lägre existensform.

I den nutida vampyrromanen är sexualiteten fortfarande knuten till en lägre livsform men nu representeras den av människan. Den mänskliga sexualiteten är ansvarslös, perverterad, snuskig och smutsig.[16] Vanliga återkommande motiv är gestaltandet av djävulsdyrkare eller sekter där sexuella perversioner lyfts fram och tydliggörs. Pedofilen, nekrofilen och den incestuösa fadern förekommer ofta i typgalleriet. Människans sexualitet har spårat ut. Vampyren ser detta och även om han själv är en mördare som dödar sina offer vänder han sig emot henne och föraktar degenerationen.

Det är inte ovanligt att vampyren griper in mot det onda i det godas skepnad. I Hotel Transylvania representeras det verkliga onda av en sekt. Ondskan motarbetas och besegras av Saint-Germain. Humanvampyrerna Ardeth och Rozokov rensar upp i den undre världen i Nancy Bakers The Night Inside (1993). I Vampire Junction räddar Timmy Valentine en ung flicka från djävulsdyrkarna "Gods of Chaos". Han tar även hand om en flicka som blivit utsatt för sexuella övergrepp av sin far. I L. J. Smiths The Vampire diaries (1991-92) är vampyren Stefan dygdens upprätthållare. Han är den noble riddaren i ny gestalt. Den vita hästen är dock utbytt mot fladdermusvingar och rustningen ersatt av en svart slängkappa.

I den nutida vampyrromanen är textens budskap till läsaren tydligt. Människans sexualitet är perverterad. Vampyren ser detta. Han föraktar uttrycken för människans sexualitet och motarbetar dem.

Jag vill inte påstå att vampyren har förlorat sin funktion som sexuell banbrytare, men hans revolt har givits en annorlunda innebörd. För vampyren tar inte endast avstånd, han erbjuder även ett alternativ, kärlek utanför den könsfixerade sexuella praktiken. Han är biologiskt impotent men inte själsligt, och när han älskar gör han det ifrån djupet av sitt inre. Enbart fysisk sexuell tillfredställelse är intet, eller ett tomt substitut för vampyren. Han nöjer sig endast med en själarnas förening. I vår samtida vampyrroman ställs det 
intellektualiserade mötet mellan två varelser i centrum. Det är det som är det eftersträvansvärda.[17]

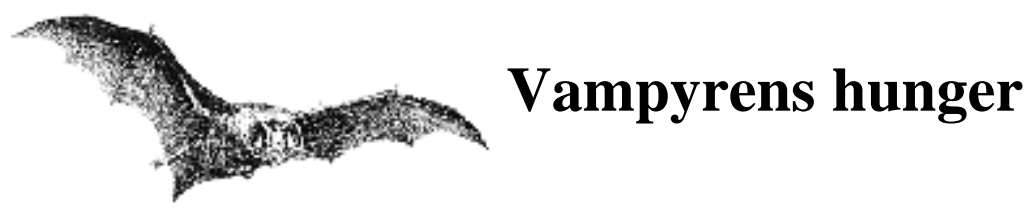

I min inledning konstaterade jag att sexualiteten varit det tema som givit upphov till de flesta akademiska tolkningsansatserna av vampyrmotivet. Jag redovisade några av de resultat som forskningen framfört. Även i den nutida vampyrromanen är sexualiteten ett tema som lockar till tolkning. Vi behöver inte som i 1700-och 1800-talens litteratur uteslutande läsa mellan raderna för att finna det vi söker efter. Sexualiteten huserar inte längre i mörkret utan står snarare i rampljuset.

Skolad i postmodernismens era blir jag misstänksam mot detta förhållande. Sexualiteten är helt enkelt alltför synliggjord. Jag tror att det är dags att göra en motläsning av vampyrromanen för att undvika att följa redan upptrampade stigar, och jag skall nu avsluta med att kort skissera hur en sådan motläsning eventuellt skulle kunna utformas.

Jag återgår därmed till den primära frågan om vad som är det mest centrala i den moderna vampyrens liv. Tveklöst cirkulerar vampyrens tankar, hela hans existens kring mat. Vampyrens blodsugande har inom forskningen oupphörligen tolkats som ett uttryck för brott mot tabubelagda sexuella handlingar. Men om vi för ett ögonblick inte betraktar vampyrens ätbeteende som laddat med sexuell symbolik, vad finner vi då? Jo, att vampyren drivs av sin hunger men inte på sex utan på mat. Vampyrens offer är hans föda. Antastandet och blodsugandet är hans sätt att förtära en måltid. Hans sexuella utstrålning är endast ett lockbete för att nå det han verkligen åtrår, blod, för det är maten som ger honom njutning och lustkänslor, inte samlaget.

Vampyren Dr Weyland konstaterar skarpt att hela hans existens cirkulerar kring hans hunger. - "Magen bestämmer.[...] " säger han. "Den kommer först och allt annat i andra hand."[18]

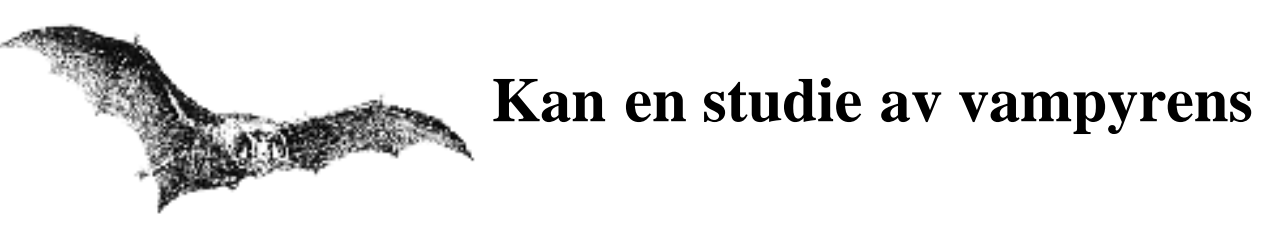

\section{matvanor öppna för nya perspektiv på vampyrmotivet?}

För ett antal år sedan gjorde jag och en studiekamrat en fältundersökning som behandlade barns förståelse av det sedelärande i fabeln. Vi lät barnen läsa Aisopos fabel om storken och räven. Räven bjuder storken på middag. Han serverar maten på fat så storken inte kan äta den. Storken hämnas dock på räven och serverar honom mat i en smal hög kanna.

Efter att barnen läst bad vi dem att berätta för oss vad fabeln handlade om. En liten pojke svarade då att det var en dum fråga, vem som helst kunde ju förstå att fabeln handlade om djuren och deras matvanor. Man kan inte förneka att pojken missuppfattade fabelns sensmoral, som du behandlar andra blir du själv bemött, men samtidigt satte han fingret på något väsentligt. Han omtolkade fabeln helt och öppnade därmed för ett nytt sätt att gripa sig an den välkända fabeln om storken och räven. 
Genom att se på vampyrromanen som en berättelse om vampyrens matvanor kan vi leda våra tankar i en annan riktning än mot sexualiteten. Jag skall nu, om än ytligt, påvisa att det finns goda grunder för att inte endast tolka vampyrens blodsugande som en omskrivning för sexuella handlingar. Låt oss därför för ett ögonblick anta att vampyrens funktion som tabubrytare inte endast koncentrerats till sexualiteten utan även till andra tabun i vår samtid.

Jag vill hävda att de mest framträdande tabun inom det västerländska välfärdssamhället är de som är knutna till maten. Föda eller förtärandet av föda är extremt laddade företeelser i vår kultur. Man kan tala om en fixering vid maten, en fixering som i flera fall föds ur en fixering vid våra kroppar. I vårt samhälle ger maten njutning och tillfredsställelse. Vi tröstäter och festäter. Maten är ett mirakelmedel som kan göra oss lyckliga.

Parallellt med vår fixering vid förtärandets njutning existerar emellertid ett annat lika överexponerat budskap, som kan sammanfattas under parollen "lyckan bor i en vacker kropp". Den vackra kroppen är den smala kroppen, den tuktade och kontrollerade. [19] Att njuta av mat och vara så smal som dagens kroppstrend anbefaller är en paradox och kroppens och förtärandets budskap har i vår tid bidragit till att sjukdomar som anorexia och bulimi blir allt vanligare.[20]

Det är inte bara i människornas värld som man kan finna ett problematiskt förhållningssätt till mat. I den nutida vampyrromanen möter vi flera vampyrer som har klara ätstörningar. Vampyren Louis finner det bestialiskt att dricka blod, och han undviker in i det sista att falla för frestelsen att äta sig riktigt mätt. Även Stefan i The Vampire diaries har ett skuldbelagt förhållande till maten. Han livnär sig likt Louis på blod från djurriket.[21] I The Night Inside är hungern det som styr vampyrens handlingar. Ardeths och Rozokovs hela existens kretsar, likt Dr Weylands, kring uppgiften att mätta sin hunger. Timmy Valentine i Vampire Junction har inte dåligt samvete för att han livnär sig på människans blod. Han mättar sin hunger, men han gör det under kontrollerade former. Han tar vad han behöver och han försöker vara så skonsam mot sitt offer som han kan. Endast vid ett fåtal tillfällen släpper Timmy sin kontroll. Då dödar han i ursinne och äter i raseri. Kopplingen mat, själslig smärta eller ångest är uppenbar i Vampire Junction. Timmy tappar endast kontrollen i situationer där han blir påmind om sin själsliga smärta. Han får alltid starka skuldkänslor efteråt.

Skuldkänslor har däremot inte kvinnorna Vicky och Lisa som blir Timmys följeslagare. I vampyrflickan Vickys lägenhet ligger resterna efter hennes måltider spridda och hon förvarar människodelar i kylen. Vicky är glupsk och hon lever endast för att äta. Timmys andra följeslagare Lisa mördar också hämningslöst, men inte för att mätta sig utan styrd av en slags okontrollerbar drift. Hon leker med maten precis som ett barn. Istället för att göra potatismosgrottor med lingonbåtar bygger hon små konstverk med huvuden av sina offer.

Timmy anser att flickorna måste civiliseras och hjälpas till rätta.

Han och de övriga humanvampyrerna som Louis, Stefan och Saint-Germain lider fortfarande av den moderna människans mattrauma. De slits mellan driften att falla för frosseriets njutning och längtan efter att bevara kontrollen över sin egen vilja och kropp. Likt anorektikern omgärdar de sina måltider med normer och regler. De vägrar att som monstervampyrerna bejaka födans frestelse. För monstret bryter mot den västerländska världens mattabu. Hon frossar ohämmat och låter sitt liv styras av magen. För henne betyder maten endast livet.

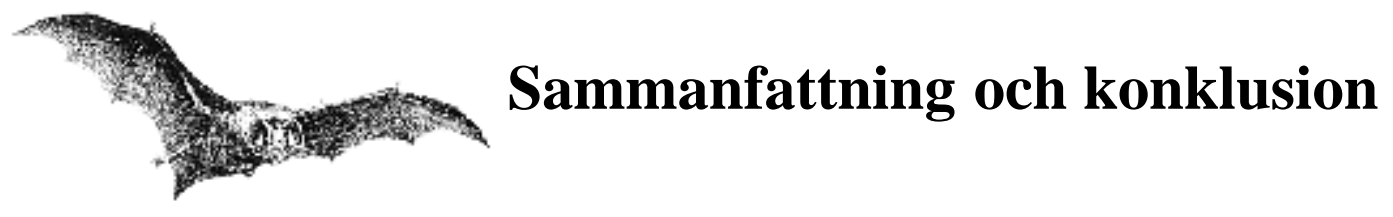


I texten ovan diskuterar jag vampyrens sexualitet som den gestaltats och gestaltas inom litteraturen. Jag inledde med att presentera några av de tongivande rösterna inom den forskning som behandlat vampyrens sexualitet. Sammanfattningsvis kan man säga att forskningen med få undantag beskriver vampyren som en sexuellt potent samvetslös erövrare som utan skuggan av ett tvivel bryter alla de sexuella tabun som den västerländska civilisationen ställt upp. Detta är en bild som inte överensstämmer med den som jag skapat mig av vampyrens sexualitet under min forskning.

Gestaltandet av sexualiteten i vampyrromanen har ändrat karaktär under historiens gång. I 1800-talets litteratur var det människan som beskrev vampyren men på 1900-talet för vampyren sin egen talan. Det förändrade berättarperspektivet har inneburit att det numera är vampyren som blottar sitt innersta rum. Det är han som reflekterar över sin egen sexualitet och människans. Och reflekterar det gör vampyren onekligen. Han bearbetar sina sexuella trauman grundligt och flera vampyrer går rentav i psykoanalys. Den nutida vampyren är sannerligen ingen samvetslös erövrare som brutit sig loss från de sexualitetens bojor som fängslar människan. I vår samtida vampyrroman är de manliga vampyrerna impotenta, kastrerade eller så har de helt enkelt valt bort praktiken av att älska som människor gör. När vampyren älskar sker det på en intellektuell nivå; det eftersträvansvärda är en själarnas och hjärnornas förening.[22]

I 1800-talets vampyrlitteratur framställdes vampyrens sexualitet som tillhörande ett lägre utvecklingsstadium. I den nutida vampyrromanen är det människans sexualitet som tycks representera det primitiva. Vampyren anser att människans sexualitet är perverterad och att den spårat ur. Han föraktar uttrycken för den samtidigt som han använder dem för att manipulera sina offer.

Gestaltandet av människors och vampyrers sexualitet i den nutida vampyrromanen behandlar motsatspar som drift/disciplin, frihet/kontroll och makt/maktlöshet. Det gör även gestaltningen av ett annat tema som jag anser vara centralt, maten.

Vampyrens hunger och hans blodsugande har inom forskningen främst tolkats som uttryck för brott mot tabubelagda sexuella handlingar. Jag anser att det är dags att nyansera bilden av vampyrens hunger och jag vill påstå att den nutida vampyren snarare hungrar efter mat än sex.[23] Maten, jakten på föda är det som upptar hela hans existens. Blodet är det som bereder honom njutning och lustkänslor, inte samlaget. Den sexuella åtrån tillhör offret. Människans tolkning att vampyren finner sexuell tillfredsställelse när han förgriper sig på henne är en projicering av offrets egna känslor. Detta innebär inte att vampyren förlorat sin roll som revolutionär tabubrytare. I den nutida vampyromanen behandlas det som verkligen är tabu i vår tid, den västerländska civilisationens mattrauma.

\section{(C) Anna Höglund}

[1] Ken Gelder, Reading the Vampire, (Routledge 1994), s. 65.

[2] Freud tillbringade en tid hos Charcot för att följa dennes arbete med att avslöja hysterins gåta. Freud praktiserade själv, likt Charcot, hypnos och suggestion i sin behandling av hysteripatienter.

[3] Ibid, s. 67.

[4] James Twitchell, "The Vampire Myth" i Margaret Carters Dracula: The Vampire and the Critics, (Ann Arbor 1988)

[5] Ken Gelder Reading the Vampire, (Routledge 1994), s. 66-69.

[6] Ibid, s. 58-64.

[7] Joan Gordon, Veronica Hollinger, Blood Read: The Vampire as Metaphor in Contemporary Culture (Pennsylvania 1997), s. 169-89.

[8] Ibid, s. 151-168. Sue-Ellen Case, "Tracking the Vampire", Differences: A Journal of

Feminist Cultural Studies 3, (1991), s. 1-20.

[9] Gelder, s. 69.

[10] Edward W Said, Orientalism, (1978) 
[11]Dracula rådfrågas den kände ungerska orientalisten Armenius Vambery av Van Helsing när denne förbereder sin kamp mot Dracula. Vambery har god kännedom om landet $\mathrm{i}$ öst (han är en del av det) och han får snabbt fram information om vampyrens bakgrund, hans karaktär och eventuella svagheter. Med hjälp av Vamberys information och sitt skarpa intellekt skapar Dr Van Helsing bilden av vampyren, monstret från öst. Vambery, som inte endast existerade i fiktionen utan i Stokers omedelbara samtid för att inte säga närhet, de möttes vid ett flertal tillfällen på The Lyceum Club i London, har i en artikel av Friedrich Kittler beskrivits som " a useful spy for the Empire, welcome at Whitehall and Downing Street [...] as well as a personal friend of the Prince of Wales. Friedrich Kittler, "Draculas Legacy" Stanford Humanities Review, 1:143-73, (1989). [12] Kultursociologen Mats Trondman använder detta begrepp i sin undersökning av klassresenären. Vampyren kan inte sägas vara en klassresenär enligt Trondmans definition, men han uppvisar flera likheter med denne. Vampyren får likt klassresenären en "dual personality". Han slits mellan det han var och det han blir. På liknande sätt som klassresenären utvecklar han en kritisk potential (använbar i analysen av omvärlden) specifik för den som lever eller har levt i två skilda "världar". Mats Trondman, Bilden av en klassresa, (Carlsson 1994).

[13] När det gäller de manliga vampyrerna i den samtida vampyrromanen har jag utöver Dr Weyland endast stött på vampyrer som har samlag på människors vis i Dan Simmons Children of the Night (1992). De tillhör likt Dr Weyland kategorin vampyrer som en egen ras. De har aldrig varit något annat än vampyrer. Det är intressant att notera att impotensproblematiken är närvarande även i Stokers Dracula. Här koncentreras den dock till den mänskliga mannen, Jonathan Harker.

[14] Michael Romkey, I, Vampire, (Toronto 1990), s. 5.

[15] Anne Rices vampyrer är bisexuella eller homosexuella. Trots att homosexuella vampyrer ofta figurerar i litteraturen vill jag påstå att den heterosexuella kärleken är dominerande både bland människor och vampyrer inom den samtida vampyrromanen. Däremot har könsrollerna inom det heterosexuella förhållandet försvagats. Kvinnan har tagit sig in på mannens domäner även på sexualitetens område. Om man ser bettet som en omskrivning för samlaget utgör både den manliga och kvinnliga vampyren den aktiva, penetrerande parten.

[16] I Bram Stokers roman blir Draculas offer vampyrer efter döden. I den samtida vampyrromanen tar dock vampyren ansvar för följderna av sina övergrepp och han använder sig av diverse preventiva åtgärder. Vampyrens "sexualitet" leder inte till oönskade "graviditeter". Han skapar inga nya vampyrer om han inte medvetet väljer att göra det.

Detta sker sällan eftersom vampyren, till skillnad från människan, tar ansvar för och värnar om sin avkomma i den samtida vampyrromanen. Delar av romanen ]Children of the Night utspelar sig på ett rumänskt barnhem. Barnen är frukten av och offren för människans ansvarslösa sexualitet. De är oönskade och övergivna. Flera av barnen är HIV-positiva och kopplingen mellan sjukdom och sexualitet betonas. Den mänskliga sexualiteten framställs som den vore av ondo.

[17] I Anne Rices vampyrkrönika existerar vampyrerna Louis och Armands förhållande på ett intellektuellt plan där den erotiska laddningen på sätt och vis är närvarande men där samlaget har spelat ut sin roll. I Somtows Vampire Junction återfår vampyren Timothy Valentine sin förmåga att älska när han under terapins långa och många samtal ges tillfälle att lära känna både sig själv och sin terapeuts inre. Även Dr Weyland får under sin terapi bli varse att han fortfarande kan känna kärlek och närhet till någon annan än sig själv. Likt Timmy riktas hans ömma känslor mot hans terapeut och likt Timmys känslor så är även Dr Weylands besvarade.

Man kan fundera på om texten ger uttryck för en konservativ hållning, ett romantiserande av tider då sexualiteten var mer oskuldsfull, mindre exploaterad än idag, eller om det snarare handlar om ett framåtsträvande än ett tillbakasträvande, en New Age-inspirerad renlevnadsfilosofi?

[18] Suzy McKee Charnas, Gästspel av vampyr, (Bra Böcker 1991), s. 141. Översättning Thomas Preis.

[19] Den utmärglade, svaga och närmast genomskinliga kvinnogestalten har i alla tider varit ett populärt litterärt och kulturellt motiv. Kvinnas svaghet och vekhet attraherar. Ju 
närmare döden desto bättre. "Den sköna kvinnans död är, utan tvekan, det mest poetiska ämnet i världen", sade Edgar Allan Poe. (The Philosophy of Composition, 1846). Ett påstående som öppnar för en mängd frågor rörande kopplingen mellan sexualitet, död, kön och makt.

[20] Under de senaste åren har det smala kvinnoidealets konsekvenser uppmärksammats både utom och inom de vetenskapliga disciplinerna. Forskningen kring sjukdomar som anorexia och bulimi har intensifierats. Detta är givetvis bra. Personligen anser jag dock att den "normala" kvinnokroppen har intagit en plats i skymundan bakom extremerna. Dagens kroppsideal är svårt att uppnå för i stort sett alla kvinnor. Svält och ätstörningar tillhör vardagen för majoriteten kvinnor, även de som inte anses sjuka. Det normala är inte längre normalt och i ivern att uppnå detta skadar vi både våra kroppar och psyken. Glädjande nog diskuteras denna problematik i en nyligen utgiven bok, Elefant i nylonstrumpor av sociologen Anna Johansson.

[21] Flera nyblivna vampyrer tycker att det är moraliskt förkastligt att dricka människoblod, trots att det bereder dem den största njutning. Eftersom vampyrer inte kan låta bli att äta väljer de ett alternativ som de inte upplever lika frånstötande, djurblod. På så sätt undviker de kannibalism. (Om man anser att vampyren är av samma art som människan.) Jag har tidigare berört den samtida vampyrromanens koppling till New Age-rörelsen. Jag finner det troligt att det brevid den sexuella renlevnadstanken existerar en matbunden sådan. I den samtida vampyrromanen problematiseras människans rätt att livnära sig på andra levande varelser. I Murphys \& Sapirs The Ultimate Death (1992) tar sig temat absurda och paradoxala former. Militanta veganvampyrer, som inte äter kött men dricker blod, gör en aktion mot en hönsuppfödningsfabrik. De slaktar samtliga anställda på samma sätt som de anställda tidigare slaktat höns. Det paradoxala i vampyrernas beteende kan möjligen förklaras genom en granskning av de dubbla budskap som Bibeln ger när det gäller förtärandet av blod. I Bibeln varnas människan för att dricka blod. Köttet skall förtäras dock inte blodet. "Ty blodet är själen och det skall du inte förtära med köttet." (Femte Moseboken 12:23-24). I Nya Testamentet uppmanar dock Jesus människan att dricka hans blod för att få evigt liv. Vampyrerna utgör det motsatta, det onda som förtär det blod som är tabu.

[22] Jag påstår att gestaltandet av sexualiteten i vampyrromanen har förändrats under tidens gång. Som jag påvisar i texten ovan har det skett förändringar men om man ser på det värde som tillskrivs den okontrollerade, driftstyrda sexualiteten kan man fråga sig hur djupgående förändringarna verkligen är? Möjligen är synen på sexualiteten konstant om man jämför 1800-talslitteraturen med 1900-talets. Det kanske bara förhåller sig så att vampyren och människan har skiftat positioner.

[23] Med det menar jag inte att det ena utesluter det andra. Ätstörningar kan givetvis kopplas till sexuella trauman. 